\title{
Drug-Resistant Tuberculosis 2020: Where We Stand
}

\author{
Angelo Iacobino $₫$, Lanfranco Fattorini $*(\mathbb{1}$ and Federico Giannoni \\ Istituto Superiore di Sanità, Department of Infectious Diseases, Via Regina Elena 299, 00161 Rome, Italy; \\ angelo.iacobino@iss.it (A.I.); federico.giannoni@iss.it (F.G.) \\ * Correspondence: lanfranco.fattorini@iss.it
}

Received: 3 March 2020; Accepted: 15 March 2020; Published: 22 March 2020

Featured Application: This comprehensive overview of drug-resistant tuberculosis will be useful for researchers to expand their knowledge beyond mechanisms other than chromosomal mutations, and for the development of novel drugs/drug combinations, hoping to shorten the therapy of the disease.

\begin{abstract}
The control of tuberculosis (TB) is hampered by the emergence of multidrug-resistant (MDR) Mycobacterium tuberculosis (Mtb) strains, defined as resistant to at least isoniazid and rifampin, the two bactericidal drugs essential for the treatment of the disease. Due to the worldwide estimate of almost half a million incident cases of MDR/rifampin-resistant TB, it is important to continuously update the knowledge on the mechanisms involved in the development of this phenomenon. Clinical, biological and microbiological reasons account for the generation of resistance, including: (i) nonadherence of patients to their therapy, and/or errors of physicians in therapy management, (ii) complexity and poor vascularization of granulomatous lesions, which obstruct drug distribution to some sites, resulting in resistance development, (iii) intrinsic drug resistance of tubercle bacilli, (iv) formation of non-replicating, drug-tolerant bacilli inside the granulomas, (v) development of mutations in Mtb genes, which are the most important molecular mechanisms of resistance. This review provides a comprehensive overview of these issues, and releases up-dated information on the therapeutic strategies recently endorsed and recommended by the World Health Organization to facilitate the clinical and microbiological management of drug-resistant TB at the global level, with attention also to the most recent diagnostic methods.
\end{abstract}

Keywords: tuberculosis; Mycobacterium tuberculosis; rifampin; isoniazid; mechanisms of resistance; mutations; granulomas; caseum; cell envelope; dormancy

\section{Introduction}

Mycobacterium tuberculosis (Mtb) is the etiologic agent of tuberculosis (TB), the leading cause of death from a single infectious disease agent worldwide [1]. In 2018, the World Health Organization (WHO) estimates of the global burden of TB were 10 million cases and 1.45 million deaths. Furthermore, about 1.7 billion people are known to be latently infected with $\mathrm{Mtb}$, with about $10 \%$ of them reactivating to active TB in their lifetime. The current antibiotic treatment of active, drug-susceptible TB, requires administration of a combination therapy for 6 months, including the first-line drugs rifampin (RIF), isoniazid (INH), pyrazinamide (PZA) and ethambutol (EMB) for 2 months, followed by RIF and INH for 4 months. To prevent reactivation of latent $\mathrm{TB}$, a long treatment is also used, consisting of at least 6 months of INH, or 3 to 4 months of RIF plus INH [1,2].

Poor regimen selection, inadequate drug supply and poor adherence of patients to the 6-months therapy may lead to development of drug-resistant Mtb strains, including multidrug-resistant (MDR: resistant at least to INH and RIF) and extensively-drug-resistant (XDR) strains [MDR resistant to a 
fluoroquinolone (FQ) and a second-line injectable drug [kanamycin (KM), amikacin (AM), capreomycin $(\mathrm{CM})$ ] [3]. Shortening the duration of therapy could increase adherence to treatment and reduce development of MDR and XDR TB.

The goal of this Review is to give a comprehensive overview of the interplay of clinical, biological and microbiological factors involved in the development of drug-resistant TB.

\section{Epidemiology of Drug Resistant TB}

WHO reported that in 2018 there were an estimated 484,000 incident cases of MDR/rifampin-resistant (RR) TB cases, including about 378,000 MDR-TB cases and 214,000 deaths [1]. The average proportion of MDR-TB cases with XDR-TB was $6.2 \%$. The countries accounting for $50 \%$ of the global burden of MDR/RR-TB were India (27\%), China (14\%) and the Russian Federation (9\%). Among 24 countries with a high TB or MDR-TB burden and representative data to second-line drugs, the proportion of MDR/RR TB cases with resistance to any FQ including ofloxacin (OFL), levofloxacin (LFX) and moxifloxacin (MFX) was 20.8\%. At the global level, 3.4\% of new cases (patients never treated with anti-TB medicines, or treated for $<1$ month) and $18 \%$ of previously treated cases (patients treated for $\geq 1$ month in the past) had MDR/RR-TB, with the highest proportion occurring in the former Soviet Union (FSU) countries. In the low incidence countries of the European Economic Area, the MDR-TB was more prevalent among migrants (particularly from the FSU) than the native population $[4,5]$.

\section{Recent WHO Recommendations for the Treatment of MDR/RR TB}

In the last decades, WHO made great efforts to facilitate and improve the treatment of patients with MDR-TB in high burden countries using various actions including the Directly Observed Treatment Strategy (DOTS)-Plus, to stress the use of second-line drugs in low- and middle-income settings, but the cure rate was lower than the WHO 2015 target of at least 75\% to 90\% [6]. For instance, treatment success for MDR/RR-TB cases started on treatment in 2016 in India, China and Russian Federation was $48 \%, 52 \%$ and $54 \%$, respectively [1].

In 2018, the results from an individual patient data meta-analysis involving 12,030 patients from 25 countries showed that treatment success and death of pulmonary MDR-TB were significantly reduced after the administration of the newer or repurposed drugs linezolid (LZD), later generation FQs, bedaquiline (BDQ), clofazimine (CFZ) and carbapenems [7]. On the basis of this and other studies, in March 2019, WHO released a new drug classification and new recommendations for the treatment of MDR-TB [8-10]. The second-line drugs were reorganized into three groups, including priority drugs [Group A: LFX or MFX, BDQ, LZD], preferentially used drugs [Group B: CFZ, cycloserine (CS) or terizidone (TRD)], and other drugs [Group C: EMB, delamanid (DLM), PZA, imipenem-cilastatin (IPM-CLN) or meropenem (MPM) (administered with clavulanic acid, CLV), AM or streptomycin (SM), ethionamide (ETO) or protionamide (PTO), para-aminosalicylic acid (PAS)].

In summary, WHO recommended an injection-free therapy (groups A and B drugs) at the initiation of MDR-TB treatment. Group C agents (oral and parenteral) should be administered when groups $\mathrm{A}$ and $\mathrm{B}$ drugs cannot be used. The commonly used second-line injectable drugs KM and CM were associated with worse outcomes [7], and were no longer recommended for the treatment of MDR-TB; AK and SM may be administered only if drug susceptibility testing (DST) confirms susceptibility.

To further reduce the burden of drug-resistant TB in the near future, in December 2019, WHO also released a Rapid Communication to inform countries and stakeholders that a regimen containing $\mathrm{BDQ}$, pretomanid (PRT, formerly PA-824) and LNZ (BPaL regimen) may be used under operational research conditions conforming to WHO standards for the treatment of XDR-TB patients [11]. This communication was released after a previous announcement of the Global TB Alliance in the second half of 2019, following the decision of the United States Food and Drug Administration (FDA) to administer BPaL (Nix-TB trial by the Global TB Alliance) to adults with pulmonary XDR-TB or intolerant/not responsive MDR-TB [12]. 


\section{Drug Resistance Mechanisms in TB}

If the 6-months combination therapy for the treatment of drug-susceptible TB is adequately taken, patients achieve cure rates of $>95 \%$, and the development of resistance by simultaneous mutations to various drugs is very rare [13]. The resistance developed by Mtb to any antimicrobial agent is not due to a single mechanism, but to the interplay of biological, clinical and microbiological reasons, including:

1. Nonadherence of patients to their 6-months therapy and/or errors of physicians in the therapy management (human errors), that increases the risk of developing genetically drug resistant bacilli $[14,15]$;

2. Complexity and poor vascularization of granulomatous lesions, which obstruct drug distribution to some sites, further leading to suboptimal drug concentration and the development of phenotypic and genetic resistance [16,17];

3. Naturally occurring high levels of antibiotic resistance in tubercle bacilli (intrinsic resistance) [18-20];

4. Formation of non-replicating (NR) drug-tolerant bacilli inside the granulomas (phenotypic resistance) [21,22];

5. Development of genetically resistant bacilli by chromosomal mutations (acquired resistance) [23-25].

\subsection{Human Errors and Advances in MDR-TB Management}

Human errors may contribute to the development of drug-resistance because of the improper use of anti-TB drugs. Two pathways lead to the development of genetic resistance: (i) primary resistance, when a person is infected with a drug-resistant strain, and (ii) acquired resistance, when a person infected with a drug susceptible strain is inadequately treated with drugs, allowing the selection of resistant mutants [13]. The first case mostly occurs in highly crowded communities (e.g., prisons), or in countries with high MDR-TB prevalence, where it is essential to rapidly diagnose and treat patients, so as to reduce transmission [15]. In the second case, it is essential to follow the WHO recommendations on how to adequately treat the TB patients whose disease is caused by a drug-susceptible strain. The clinicians need also to ensure that infection control measures are established, particularly when MDR-patients are hospitalized [26].

To implement the Stop TB Strategy (developed from the DOTS framework), WHO identified a number of factors contributing to poor treatment outcomes, including the acquisition of acquired drug-resistant TB [13]. They were: (i) Inappropriate treatment by health care providers (inappropriate or absent guidelines, poor training of physicians and nurses, sub-optimal education of patients, poor management of adverse drug reactions, no monitoring of treatment, poorly organized or funded TB control programs); (ii) Inadequate drug supply (poor quality medicines, stock-outs, poor storage conditions, wrong dose or combination); (iii) Inadequate drug intake or treatment response by patients (lack of information on treatment adherence, adverse effects, malabsorption).

Common clinical errors in MDR-TB management, particularly in developing countries, include the addition of a single drug to a failing regimen, failure to recognize existing drug resistance, failure to provide directly observed therapy and to manage nonadherence, suboptimal dosages of second-line drugs to decrease side effects, drug treatment based on clinical facts while waiting for DST results $[13,14]$. In any case, it is important to know that only drug combinations decrease the risk of selection of resistant strains.

Since the treatment of MDR/XDR-TB cases is difficult, WHO recommended that their management be performed by a multidisciplinary team (TB Consilium) at local, regional and/or national levels, including experts (e.g., clinicians, microbiologists, public health officers) with different professional backgrounds $[13,15]$. In medium and high incidence countries, TB Consilia are important for accessing second-line drugs and/or new drugs BDQ and DLM. 
A comparative analysis of the TB Consilia for management of difficult-to-treat MDR/XDR TB cases in Europe and Latin America has been reported [27]. In October 2018, a Global TB Consilium was launched by the Global TB Network, with the goal to provide to a clinician a response on difficult TB cases within $48 \mathrm{~h}[15,28]$.

\subsection{Complexity of TB Granulomas}

Long lasting therapies are also attributable to the complex pathology of TB. In the lungs of patients with active and latent $\mathrm{TB}$, a spectrum of heterogeneous granulomatous lesions coexist, ranging from well-vascularized cellular granulomas, in which a rim of lymphocytes surrounds macrophages and neutrophils, to avascular caseous granulomas, characterized by a necrotic center with a cheese-like aspect (caseum) formed by the lysis of host cells and bacteria $[29,30]$. In these lesions, tubercle bacilli range from actively replicating (AR) stages, particularly in cellular granulomas, to dormant, slowly-replicating or NR stages, typical of hypoxic caseous granulomas [31]. In Mtb-infected rabbits, the fraction unbound of a drug penetrates the caseum via passive diffusion, and caseum binding of a drug is proportional to hydrophobicity (cLogP) and aromatic ring count [32].

The current 4-drugs therapeutic regimen (RIF-INH-PZA-EMB) is effective against AR intracellular bacilli in cellular granulomas, while NR extracellular bacilli localized in $\mathrm{pH}$-neutral, caseous granulomas are refractory to drug action [17,33-36]. The necrotic center of caseous granulomas contains NR bacilli phenotypically resistant to several drugs (drug-tolerant persisters), with the exception of rifamycins, which are known to sterilize caseum in ex-vivo assays $[35,36]$. Spatial and temporal differences in drug distribution and the kinetics of accumulation of drugs in specific lesion compartments may create local windows of monotherapy that increase the risk of the emergence of drug-resistance $[17,37]$. This is in keeping with the knowledge that genetically resistant mutants of Mtb may emerge from the persistence phase of some TB drugs, due to hydroxyl radical-mediated genome-wide random mutagenesis [38-40]. In this view, drug combinations should contain complementary drugs preferentially distributing in lesions in which their most vulnerable target population resides [17].

In the event of caseous granulomas expansion, the necrotic centers fuse with the airway structures of bronchi to form pulmonary cavities in which are found both extracellular bacilli from liquefied caseum and intracellular bacilli derived from the lysis of infected macrophages of the cavity walls. In contact with the atmospheric oxygen, these bacilli rapidly proliferate in the lumen of cavities, and later appear in the sputum of TB patients [17]. Due to high bacterial load in pulmonary cavities, genetically resistant bacilli with chromosomal mutations may be generated, playing an important role in the development of resistance [16]. Noticeably, in comparison with paired sputum isolates, additional resistances were found in $\mathrm{Mtb}$ isolates recovered from surgically resected cavities of the same patient [41]. A single founder Mtb strain underwent genetic mutations during treatment, leading to the acquisition of additional drug resistance in different sections of the lung of the same patient, preferentially in the cavity wall [42]. In keeping with this observation, drug-specific gradients in the walls of human pulmonary cavities were reported to be associated with the development of acquired resistance in patients with MDR-TB, due to the low level of some drugs in the cavities centers, where there is a high number of replicating bacilli [43]. In the latter study, spatial heterogeneity of drug concentrations across the pulmonary cavity resulted in the development of mutations in the Mtb genes gyrA (FQ resistance) and $g y d B$ (aminoglycoside resistance), consistent with evolution from MDR- to XDR-TB after about five months of therapy [43]. Overall, these observations indicate that acquired $\mathrm{Mtb}$ resistance may be related to the formation of drug-penetration gradients in TB lesions generating suboptimal drug concentrations in non-vascularized caseous granulomas and in liquefied caseum in the cavity centers $[16,17,43]$.

\subsection{Intrinsic Drug-Resistance of $M t b$}

During the evolution, Mtb developed mechanisms of intrinsic resistance to antibiotics involving cell envelope, efflux systems and other mechanisms (drug degradation and modification, target 
modification), which allowed the organism to reach high drug resistance levels. Some examples of these mechanisms are provided in the following sections.

\subsubsection{Cell Envelope}

The constituents of the mycobacterial cell envelope are: the cytoplasmic membrane, the periplasmic space (PS), a network of peptidoglycan (PG), the arabinogalactan (AG), the long-chain mycolic acids (MA) and the capsule, made of a loose matrix of glucans and secreted proteins [44]. As to the first-line TB drugs, the bactericidal agent INH inhibits MA synthesis, while the bacteriostatic EMB inhibits AG synthesis and may sensitize Mtb to other drugs [44].

It is assumed that the innermost hydrophilic layers of PG and AG hinder the penetration of hydrophobic molecules. Instead, in the external part of the envelope, the PG and AG layers are linked to the hydrophobic MA layer, formed by long-chain fatty acids that restrict the penetration of hydrophilic drugs $[18,20]$. In principle, more lipophilic drugs, such as rifamycins, macrolides, and some FQs, diffuse by passive transport into and through the lipid-rich cell wall [45,46]. In early studies, mutants defective in the biosynthesis of cell wall components were very useful to demonstrate the role of the cell wall in the intrinsic resistance to drugs. For instance, a mycolate defective Mycobacterium smegmatis mutant showed increased susceptibility to RIF, chloramphenicol (CF), novobiocin and erythromycin $[47,48]$. Also, insertions in genes involved in the mycolate biosynthesis of Mtb (mymA operon) showed enhanced chemical penetration and sensitivity to RIF, INH, PZA and ciprofloxacin [49].

Small hydrophilic drugs traverse the cell wall of bacteria via water-filled porins, without energy consumption. M. tuberculosis encodes at least two porin-like proteins (OmpA, encoded by Rv0899 and Rv1698), but the role of porins in Mtb drug uptake and susceptibility needs to be further investigated $[18,20,50,51]$. Penetration of hydrophilic $\beta$-lactam antibiotics through the mycobacterial cell was about 100 times lower than in the Escherichia coli cell wall [20]. The $\beta$-lactamases, probably in conjunction with slow drug penetration, were shown to be major determinants of Mtb resistance to $\beta$-lactams [52,53]. In Mtb, the PG is remodeled by nonclassical L,D-transpeptidases (LDT). The structural basis and the inactivation mechanism of LDT and the active role of carbapenems were investigated, providing a basis for their potential use in inhibiting Mtb [54]. Indeed, the carbapenems IPM-CLN and MPM (both to be used with CLV, available only in formulations combined with amoxicillin) have been listed as add-on drugs in the recent WHO treatment guidelines of MDR/XDR TB [8].

Overall, it is thought that anti-TB drugs have the peculiarity of being more lipophilic than many other antimicrobial agents, likely due to improved penetration through the waxy mycobacterial cell wall $[45,46]$. However, the issue is perhaps more complex, since some studies showed that lipophilicity is an important but not exclusive factor of compound permeability [50,55].

\subsubsection{Drug Efflux}

Efflux pumps (EPs) are transmembrane proteins that provide resistance by expelling the drugs from the interior to the exterior of the cell. Five EP families are known, organized on the basis of energetic and structural characteristics: the ATP-binding cassette (ABC) superfamily, the major facilitator superfamily (MFS), the multidrug and toxic compound extrusion (MATE) family, the small multidrug resistance (SMR) family and the resistance nodulation division (RND) superfamily $[18,19,46,56,57]$. The ATP-energized ABC members are primary transporters, while the others are secondary transporters energized by proton gradients (MFS, SMR, RND) or sodium gradients (MATE). The EP of Mtb belongs to the ABC (representing 2.5\% of the entire Mtb genome), MFS and RND superfamilies, and to the SMR family.

Following exposure of Mtb to sub-inhibitory concentration of INH and EMB, EP genes are overexpressed resulting in the development of low-level resistance for a prolonged period of time. After several weeks, a high level of acquired resistance develops, caused by chromosomal mutations in the genes encoding the target proteins $[58,59]$. These observations indicate that inappropriate TB 
treatment may generate pressure by sub-inhibitory drug concentrations that increase drug efflux, allowing a subsequent selection of mutants with high-level resistance [46,57].

Several EPs are known to be associated with resistance. For instance, Mtb exposure to INH induces the overexpression of MmpL7 and $m m R$ EP genes [60,61]. Furthermore, several EPs are involved in resistance to several drugs. Thus, the EP Tap mediates low-level resistance to tetracycline (TC) and aminoglycosides, whereas EPs encoded by the $R v 0194$ gene is associated with resistance to $\beta$-lactams, $\mathrm{SM}, \mathrm{TC}, \mathrm{CF}$ and vancomycin. Mutations in the Rv0678 gene caused an up-regulation of the transport protein, MmpL5, which caused EP-mediated cross-resistance to both BDQ and CFZ [60,62,63]. This is a potentially dangerous evolution of $\mathrm{Mtb}$ against antibiotics particularly in recent times, since BDQ and CFZ have just been included in the new WHO treatment guidelines of MDR/XDR-TB $[8,11]$.

A strategy used to inhibit efflux-mediated drug resistance is efflux inhibition by non-antibiotic molecules that block the EP or inhibit the EP energy sources [57,64]. The most studied inhibitors are verapamil (VP), thioridazine (TZ), reserpine, piperine, protonophores $[57,64]$, to be used in combination with anti-TB drugs in order to decrease or abolish the drug resistance caused by EP activity. Verapamil, an FDA-approved calcium channel blocker, decreased the MICs of BDQ, CFZ and other drugs [57]. This synergism was confirmed in various studies, but it was found that the effect of VP was not due to intra-mycobacterial drug accumulation, but on the disruption of membrane functions [65]. In Mtb-infected mice, VP increased the bioavailability and efficacy of BQ but not CFZ [66]. EP inhibitors are not presently used for the treatment of human $\mathrm{TB}$, with the exception of $\mathrm{TZ}$, which was administered in compassionate therapy for some XDR-TB cases [67].

\subsubsection{Other Mechanisms}

The most important mechanisms of the intrinsic drug resistance of Mtb are considered to be the lipid-rich cell wall and the EP, but other systems are known to neutralize toxic chemicals and antibiotics, including drug inactivation or modification, and target modification.

Among drug inactivating enzymes, Mtb $\beta$-lactamases are less effective than those of other bacteria to hydrolyse $\beta$-lactams, but their activity, together with slow penetration across the cell wall and low affinity for penicillin-binding proteins, is good enough to render Mtb intrinsically resistant to most $\beta$-lactams $[18,20]$. The most important Mtb $\beta$-lactamase $(\mathrm{BlaC})$ is thought to localize in the PS, and shows broad substrate specificity, including carbapenems, which are usually resistant to the $\beta$-lactamases of other bacteria. BlaC is inhibited by CLV that, as mentioned above, must be added to IPM- or MPM-containing prescriptions, as salvage WHO regimens for treatment of MDR/XDR-TB [8].

As to aminoglycosides (KM, AK) and cyclic peptides (CP), Mtb is able to inactivate them by acetylation performed by the enhanced intracellular survival protein encoded by eis, whose expression is upregulated by the MDR transcription regulator WhiB7 [20]. Promoter mutations lead to an overexpression of eis, resulting in low-level resistance to KM, but not AK [68].

M. tuberculosis is naturally resistant to macrolides (e.g., clarithromycin and azithromycin) because of the inducible erm(37), a ribosomal RNA methyltransferase which alters ribosomes by methylating the $23 \mathrm{~S}$ rRNA $[69,70]$. Other erm genes conferring inducible resistance to FQs were found in non-tuberculous mycobacteria [71]. Intrinsic resistance to FQ is also attributed to a pentapeptide repeat protein called MfpA, which mimic the size, shape and surface charge of duplex DNA by resembling the 3D structure of a DNA double helix [20,72].

As to resistance to the broad-spectrum agent fosfomycin, Mtb is intrinsically resistant to this agent, which inhibits the MurA enzyme, involved in the biosynthesis of PG, because a cysteine residue in the active site of Mtb MurA is changed into aspartic acid [73].

\section{Phenotypic Drug-Resistance of Mtb}

Caseous granulomas and the cavities of the lungs of TB patients harbor subpopulations of NR bacilli which are phenotypically drug-resistant but genetically susceptible, commonly referred to as persisters. Characterized by a transient, non-heritable drug tolerance, persisters are capable of 
withstanding bactericidal drug concentrations, and once the antibiotic is removed, to resume growth with genetic features identical to the original strain.

The level of resistance to different antimicrobial agents varies with the in vitro stress model used [31-34,74-77], including hypoxia (Wayne dormancy model) [78,79], nutrient starvation [80], acids and/or nitric oxide [81,82], stationary phase [83], antibiotic-starved strains [84] and others, or their variants. In the Wayne model, in which dormant bacilli are obtained by a gradual adaptation to anaerobiosis through the self-generated formation of an oxygen gradient, nonreplicating persistence (NRP) stages 1 and 2 were observed [78]. NRP-2 cells developed a thickened outer layer that helped in restricting RIF entry [85]. Our group used the Wayne model at different $\mathrm{pHs}$ : $\mathrm{pH}$ 6.6, the $\mathrm{pH}$ or culture media [86], $\mathrm{pH} 5.8$, to mimic the environment of cellular granulomas [87], $\mathrm{pH} 7.3$, to mimic the environment of caseous granulomas [88]. We found that at pH 5.8, several drugs killed NR bacilli, with the best being the rifamycins RIF and rifapentine (RFP), while at pH 7.3, only RIF and RFP killed dormant bacilli out of 12 drugs tested [88]. Since the rifamycins were the only agents sterilizing caseum obtained from rabbits [35,36], our model could mimic caseum to measure drug activity against NR Mtb in this environment. In hypoxia at $\mathrm{pH}$ 7.3, we found that RIF plus nitazoxanide (a nitro-compound for anaerobic infections) killed NR Mtb cells, while the combination currently used for human TB therapy (RIF-INH-PZA-EMB) did not [89].

Two kinds of persisters are known [74]: (i) Class I, rare, generated in a replicating population, formed continuously and in a purely stochastic manner. They are bacilli phenotypically tolerant to different antibiotics by different mechanisms, and it is likely that the overall population can be killed by drug combinations; (ii) Class II, abundant, involving almost all of the cells in a population, e.g., in the stationary phase, hypoxic conditions, nutrient starvation. Growth arrest is associated with resistance to a large number of drugs, and it is likely that new kinds of antibiotics are necessary to overcome these cells [74].

Dormancy is not necessary or sufficient for Mtb persistence, indicating that persistence is a phenomenon more complex than dormancy, and that additional characteristics are needed to define the persister phenotypes, which depends on the NR model used [90]. A poor correlation was found between the transcriptomes of class I persisters enriched by cycloserine [91] and class II persisters obtained under hypoxia, the stationary phase or nutrient starvation [74]. On the other hand, persister diversity is expected also from the different host environments in which these specialized cells live, ranging from the intracellular location in the phagosomes to extracellular life in the caseum. In BDQ-treated guinea pigs, persisting bacilli where located in the acellular rim of necrotic lesions, morphologically similar to human TB lung lesions [92].

The state of non-replication is associated with phenotypic drug-tolerance, but different stresses may induce phenotypically different bacilli. Few compounds were dual active molecules with bactericidal activity against both replicating and NR Mtb. They included RIF, BDQ, PRT and MFX, which target RNA polymerase, ATP synthase, cell wall synthesis/cell respiration, and DNA gyrase, respectively $[24,31,74]$. In $\mathrm{BALB} / \mathrm{c}$ mice, persisters were eradicated by regimens containing high-dose RIF and BDQ [93,94]. In BALB/c mice, C3HeB/FeJ caseum-forming mice and athymic nude mice, PRT contributed significantly to the efficacy of BDQ-containing regimens, with either LZN (BPaL regimen) or MFX and PZA (BPaMZ regimen) [95].

Interestingly, RIF-resistant or MXF resistant mutants carrying mutations in rpoB or gyr $A$ genes emerged at high frequency from the persistent phase of Mtb cells exposed to RIF for prolonged periods. These cells carried elevated levels of the hydroxyl radical, which inflicted genome-wide mutations facilitating resistance to the same, or another, antibiotic [38,39]. In consideration of the long TB therapy, these observations may have clinical significance in the emergence of drug-resistant mutants if local monotherapy occurs in patients who do not correctly take multi-drug TB therapy.

In this view, it was postulated that persisters behave as an evolutionary reservoir from which drug-resistant mutants can emerge [22]. 
Thus, targeting NR persisters could reduce the duration of antibiotic treatment and rate of post-treatment relapse $[74,96]$. Researches aimed at better understanding the relationship between persistence and resistance, and at finding novel drug combinations for killing both AR and NR bacilli, will provide new strategies to shorten TB therapy.

\section{Acquired Drug-Resistance of Mtb}

A cocktail of different drugs is used to treat TB. Each molecule binds to one or more target, thus inhibiting their functions. The continuous drug exposure during lengthy treatments and the noncompliance of patients to drug regimens, pushes $\mathrm{Mtb}$ to select for mutations in genes encoding drug targets, responsible for development of the majority of resistances in clinical strains [20]. A list of the major target genes that, in the case of mutation, confer resistance to the drugs of the WHO groups $\mathrm{A}$, $\mathrm{B}$ and $\mathrm{C}$, is shown in Table 1 [97-125]. Many excellent reviews report the genetic mechanisms involved in this resistance to RIF, INH, KM, CP and other drugs [18,23,24,98,118,126].

Table 1. Drugs of the World Health Organization (WHO) groups A, B and C, and list of the most common drug resistance-related target genes.

\begin{tabular}{|c|c|c|c|c|}
\hline Group & Drug & Target Gene/s & Gene Product (Function Affected) & References \\
\hline \multirow[t]{6}{*}{ A } & LFX or MFX & gyrA & $\begin{array}{l}\text { DNA gyrase, subunit A (DNA } \\
\text { replication) }\end{array}$ & {$[97,98]$} \\
\hline & & $g y r B$ & $\begin{array}{l}\text { DNA gyrase, subunit B (DNA } \\
\text { replication) }\end{array}$ & {$[98,99]$} \\
\hline & BDQ & $a t p E$ & $\begin{array}{c}\text { ATP synthase, subunit F0 (ATP } \\
\text { synthesis) }\end{array}$ & {$[100,101]$} \\
\hline & & $r v 0678$ & Transcriptional regulator (drug efflux) & {$[100,101]$} \\
\hline & LNZ & $r p l C$ & $\begin{array}{c}50 S \text { ribosomal protein L3 (protein } \\
\text { synthesis) }\end{array}$ & {$[100,102]$} \\
\hline & & $r r l$ & 23S RNA (protein synthesis) & {$[100,102]$} \\
\hline \multirow[t]{4}{*}{ B } & CFZ & $r v 0678$ & Transcriptional regulator (drug efflux) & {$[100,103]$} \\
\hline & & $r v 1979 c$ & $\begin{array}{l}\text { (Possible permease involved in } \\
\text { aminoacid transport) }\end{array}$ & {$[100,103]$} \\
\hline & & rv2535c & (PepQ putative aminopeptidase) & {$[103,104]$} \\
\hline & CS or TRD & alr & $\begin{array}{c}\text { Alanine racemase (peptidoglycan } \\
\text { synthesis) }\end{array}$ & [105] \\
\hline \multirow[t]{8}{*}{$\mathrm{C}$} & EMB & $e m b C A B$ & $\begin{array}{l}\text { Arabinofuranosyltransferases } \\
\text { (arabinogalactan synthesis) }\end{array}$ & {$[106,107]$} \\
\hline & & ubiA & $\begin{array}{l}\text { Phosphoribosyltransferase (cell wall } \\
\text { synthesis) }\end{array}$ & {$[108,109]$} \\
\hline & DLM & $d d n$ & $\begin{array}{c}\text { Deazaflavin }\left(\mathrm{F}_{420}\right) \text {-dependent } \\
\text { nitroreductase (mycolic acid } \\
\text { synthesis) }\end{array}$ & [110] \\
\hline & & $f g d-1$ & $\begin{array}{l}\text { Glucose-6-phosphate dehydrogenase } \\
\qquad\left(\mathrm{F}_{420} \text { synthesis }\right)\end{array}$ & [110] \\
\hline & & fbiA & Protein FbiA ( $\mathrm{F}_{420}$ synthesis) & [110] \\
\hline & & $f b i B$ & Protein $\mathrm{FbiB}$ (F420 synthesis) & [110] \\
\hline & & fbiC & Protein FbiC ( $\mathrm{F}_{420}$ synthesis) & {$[110]$} \\
\hline & PZA & pncA & $\begin{array}{l}\text { Pyrazinamidase (conversion of PZA } \\
\text { into pyrazinoic acid, resulting in } \\
\text { dysfunctions of membrane potential) }\end{array}$ & {$[98,111]$} \\
\hline
\end{tabular}


Table 1. Cont.

\begin{tabular}{|c|c|c|c|c|}
\hline Group & Drug & Target Gene/s & Gene Product (Function Affected) & References \\
\hline & & $r p s A$ & $\begin{array}{l}30 S \text { ribosomal protein } \mathrm{S} 1 \text { (m-RNA } \\
\text { trans-translation) }\end{array}$ & {$[23,111]$} \\
\hline & & panD & $\begin{array}{l}\text { Aspartate decarboxylate } \\
\text { (panthotenate synthesis) }\end{array}$ & {$[111,112]$} \\
\hline & & $\operatorname{clpc1}$ & $\begin{array}{l}\text { ATP-dependent ATP-ase (protein } \\
\text { degradation) }\end{array}$ & {$[23,113]$} \\
\hline \multirow{3}{*}{\multicolumn{2}{|c|}{$\begin{array}{l}\text { IPM-CLN } \\
\text { or MPM }\end{array}$}} & ro2518c & $\begin{array}{l}\text { LdtB, nonclassical, L,D-transpeptidase } \\
\text { (peptidoglycan synthesis) }\end{array}$ & {$[19,54,114,115]$} \\
\hline & & rv3682 & $\begin{array}{l}\text { PonA2, penicillin-binding protein } \\
\text { (peptidoglycan synthesis) }\end{array}$ & {$[19,114]$} \\
\hline & & $R v 2068 c$ & blaC ( $\beta$-lactamase $)$ & [116] \\
\hline & $\mathrm{AM}$ & $r r s$ & $\begin{array}{l}\text { 16S ribosomal RNA (protein } \\
\text { synthesis) }\end{array}$ & {$[98,117]$} \\
\hline \multirow{3}{*}{\multicolumn{2}{|c|}{$\mathrm{SM}$}} & rpsl & $\begin{array}{l}\text { ribosomal protein S12 (protein } \\
\text { synthesis) }\end{array}$ & {$[98,118]$} \\
\hline & & $r r s$ & $\begin{array}{l}\text { 16S ribosomal RNA (protein } \\
\text { synthesis) }\end{array}$ & {$[98,117]$} \\
\hline & & $\operatorname{gidB}$ & $\begin{array}{l}\text { (putative 16S rRNA } \\
\text { methyltransferase) }\end{array}$ & {$[119,120]$} \\
\hline \multirow{5}{*}{\multicolumn{2}{|c|}{ ETO or PTO }} & $r v 0565 c$ & $\begin{array}{l}\text { Monoxygenase (activation of } \\
\text { pro-drugs ETO and PTO) }\end{array}$ & [121] \\
\hline & & ethA & $\begin{array}{c}\text { Monooxygenase (activation of ETO } \\
\text { and PTO) }\end{array}$ & {$[19,122]$} \\
\hline & & $m y m A$ & $\begin{array}{c}\text { Monooxygenase (activation of ETO } \\
\text { and PTO) }\end{array}$ & {$[121,123]$} \\
\hline & & $k a t G$ & $\begin{array}{c}\text { Catalase-peroxidase (activation of } \\
\text { ETO, PTO, INH) }\end{array}$ & [122] \\
\hline & & $\operatorname{inh} A$ & $\begin{array}{l}\text { Enoyl-ACP reductase (mycolic acid } \\
\text { synthesis) }\end{array}$ & {$[98,122]$} \\
\hline \multirow{3}{*}{\multicolumn{2}{|c|}{ PAS }} & thyA & Thymidylate synthase & {$[23,124]$} \\
\hline & & folC & Dihydropholate synthase & {$[23,125]$} \\
\hline & & $d f r A$ & Dihydropholate reductase & {$[23,125]$} \\
\hline
\end{tabular}

Phenotypic testing is still considered a gold standard for Mtb DST, which is accurate, but takes at least two weeks for results [98]. However, a pivotal role has been recently played by the more and more rapid molecular methods to diagnose drug-resistant TB by the identification of chromosomal mutations, including line probe assays, the Xpert MTB/RIF system (Cepheid, Sunnyvale, CA, USA), target gene sequencing, whole genome sequencing (WGS), point-of-care nucleic acid amplification devices $[9,127,128]$.

The Treatment Action Group (TAG) recently released the pipeline report 2019 on TB diagnostics [129]. The TAG-stratified DST tests for decentralized and centralized laboratories. Useful information was provided on what it is currently in TB diagnostics, including tests already recommended by the $\mathrm{WHO}$, and on which tests are expected to be available soon. As to the decentralized tests, the Xpert MTB/RIF assay (sensitivity and specificity for RIF resistance of $96 \%$ and $98 \%$, respectively) was recommended by the WHO in 2010, and entered in the market in the same year. The sensitivity of this assay increased with the 2017 rollout of the Xpert MTB/RIF Ultra cartridge. In 2020, there is expected the WHO evaluation and market entry of Xpert XDR, which will detect resistance to INH, 
MFX, OFL, AK and KM [129]. In 2013, another company (Molbio Diagnostics, Goa, India) released its systems Truenat MTB and Truenat MTB-RIF Dx onto the Indian market [129]. In January 2020, a rapid WHO Communication reported that the Truenat systems MTB, MTB Plus and MTB RIF Dx assays showed comparable accuracy with Xpert MTB/RIF and Xpert Ultra for Mtb detection (Truenat MTB and Truenat MTB Plus), and for sequential RIF resistance detection (Truenat MTB RIF Dx) [130]. Furthermore, the data for Truenat MTB RIF Dx showed similar accuracy to the WHO approved commercial line probe assays indicated by the TAG for centralized DST [GenoType MTBDRplus Version 2.0 (Hain Lifescience, Nehren, Germany) and Nipro NTM+MDRTB detection kit2 (Nipro, Osaka, Japan)] $[129,130]$. Other systems marketed in 2015-2019 and on the pathway to the WHO evaluation for the centralized determination of molecular resistance to INH and RIF are: Cobas MTB-RIF/INH (Roche, Basel, Switzerland), BD MAX MDR-TB (Becton Dickinson, Sparks, MA, USA), real-time MTB-RIF/INH Resistance assay (Abbott, Abbott Park, IL, USA) and FluoroType MTBDR version 2.0 (RIF, INH) (Hain Lifescience) [129,131-133].

Finally, the WGS technology is capable of identifying the complete drug-resistance profile of an Mtb strain, ideally enabling clinicians to obtain the best anti-TB treatment $[98,128,130,134]$. However, more data are still needed to correlate genetic mutations with phenotypic resistance, in order to definitely guide the clinical care.

In this view, the initiative of the Comprehensive Resistance Prediction for Tuberculosis: an International Consortium (CRyPTIC) project aims at understanding the relationship between genotypes and resistance by sequencing 100,000 whole TB genomes from various countries, in parallel with comprehensive DST assays. Overall, at this stage, the WGS still needs more studies, but it is commonly believed that this technology will be the future of rapid, centralized DST [129,135].

\section{Conclusions}

Drug-resistant TB is a significant challenge for the successful control of the disease worldwide. A comprehensive review of clinical, biological and microbiological issues favoring resistance development has been provided, helping in the development of new tools for the rapid diagnosis and treatment of drug-resistant TB. The review was based on the most recent updates on drug resistance mechanisms reported in the literature, and on the international recommendations of WHO to facilitate the clinical and microbiological management of MDR/XDR TB at global level.

Author Contributions: Conceptualization, writing, reviewing and editing: A.I., L.F., F.G. All authors have read and agree to the published version of the manuscript.

Funding: This research received no external funding.

Conflicts of Interest: The authors declare no conflict of interest.

\section{References}

1. World Health Organization. Global Tuberculosis Report 2019; World Health Organization: Geneva, Switzerland, 2019.

2. Zenner, D.; Beer, N.; Harris, R.J.; Lipman, M.C.; Stagg, H.R.; van der Werf, M.J. Treatment of Latent Tuberculosis Infection: An Updated Network Meta-analysis. Ann. Intern. Med. 2017, 67, 248-255. [CrossRef]

3. Nahid, P.; Mase, S.R.; Migliori, G.B.; Sotgiu, G.; Bothamley, G.H.; Brozek, J.L.; Cattamanchi, A.; Cegielski, J.P.; Chen, L.; Daley, C.L.; et al. Treatment of Drug-Resistant Tuberculosis. An Official ATS/CDC/ERS/IDSA Clinical Practice Guideline. Am. J. Respir. Crit. Care Med. 2019, 200, e93-e142. [CrossRef] [PubMed]

4. Mustazzolu, A.; Borroni, E.; Cirillo, D.M.; Giannoni, F.; Iacobino, A.; Italian Multicentre Study on Resistance to Antituberculosis Drugs (SMIRA); Fattorini, L. Trend in rifampicin-, multidrug- and extensively drug-resistant tuberculosis in Italy, 2009-2016. Eur. Respir. J. 2018, 52. [CrossRef] [PubMed]

5. Bernard, C.; Brossier, F.; Sougakoff, W.; Veziris, N.; Frechet-Jachym, M.; Metivier, N.; Renvoisé, A.; Robert, J.; Jarlier, V. MDR-TB Management group of the NRC. A surge of MDR and XDR tuberculosis in France among patients born in the Former Soviet Union. Euro Surveill. 2013, 18. [CrossRef] 
6. Kibret, K.T.; Moges, Y.; Memiah, P.; Biadgilign, S. Treatment outcomes for multidrug-resistant tuberculosis under DOTS-Plus: A systematic review and meta-analysis of published studies. Infect. Dis. Poverty. 2017, 6. [CrossRef] [PubMed]

7. Ahmad, N.; Ahuja, S.D.; Akkerman, O.W.; Alffenaar, J.C.; Anderson, L.F.; Baghaei, P.; Bang, D.; Barry, P.M.; Bastos, M.L.; Behera, D.; et al. Collaborative Group for the Meta-Analysis of Individual Patient Data in MDR-TB treatment-2017. Lancet. 2018, 392, 821-834. [CrossRef]

8. World Health Organization. WHO Consolidated Guidelines on Drug-Resistant Tuberculosis Treatment; World Health Organization: Geneva, Switzerland, 2019.

9. Dheda, K.; Gumbo, T.; Maartens, G.; Dooley, K.E.; Murray, M.; Furin, J.; Nardell, E.A.; Warren, R.M. On behalf of the Lancet Respiratory Medicine drug-resistant tuberculosis Commission group. The Lancet Respiratory Medicine Commission: 2019 update: Epidemiology, pathogenesis, transmission, diagnosis, and management of multidrug-resistant and incurable tuberculosis. Lancet Respir. Med. 2019, 7, 820-826. [CrossRef]

10. Lange, C.; Chesov, D.; Furin, J.; Udwadia, Z.; Dheda, K. Revising the definition of extensively drug-resistant tuberculosis. Lancet Respir. Med. 2018, 6, 893-895. [CrossRef]

11. World Health Organization. Rapid Communication: Key Changes to the Treatment of Drug-Resistant Tuberculosis; World Health Organization: Geneva, Switzerland, 2019.

12. TB Alliance. Available online: https://www.tballiance.org/news/fda-advisory-committee-votes-favorablyquestion-effectiveness-and-safety-pretomanid-combination (accessed on 24 February 2020).

13. World Health Organization. Companion Handbook to the WHO Guidelines for the Programmatic Management of Drug-Resistant Tuberculosis; World Health Organization: Geneva, Switzerland, 2014.

14. Monedero, I.; Caminero, J.A. Common errors in multidrug-resistant tuberculosis management. Expert Rev. Respir. Med. 2014, 8, 15-23. [CrossRef]

15. Tiberi, S.; Pontali, E.; Tadolini, M.; D'Ambrosio, L.; Migliori, G.B. Challenging MDR-TB clinical problems-The case for a new Global TB Consilium supporting the compassionate use of new anti-TB drugs. Int. J. Infect. Dis. 2019, 80, S68-S72. [CrossRef]

16. Strydom, N.; Gupta, S.V.; Fox, W.S.; Via, L.E.; Bang, H.; Lee, M.; Eum, S.; Shim, T.; Barry, C.E.; Zimmerman, M.; et al. Tuberculosis drugs' distribution and emergence of resistance in patient's lung lesions: A mechanistic model and tool for regimen and dose optimization. PLoS Med. 2019, 16. [CrossRef] [PubMed]

17. Dartois, V. The path of anti-tuberculosis drugs: From blood to lesions to mycobacterial cells. Nat. Rev. Microbiol. 2014, 12, 159-167. [CrossRef] [PubMed]

18. Singh, R.; Dwivedi, S.P.; Gaharwar, U.S.; Meena, R.; Rajamani, P.; Prasad, T. Recent updates on drug resistance in Mycobacterium tuberculosis. J. Appl. Microbiol. 2019. [CrossRef]

19. Nasiri, M.J.; Haeili, M.; Ghazi, M.; Goudarzi, H.; Pormohammad, A.; Imani Fooladi, A.A.; Feizabadi, M.M. New Insights in to the Intrinsic and Acquired Drug Resistance Mechanisms in Mycobacteria. Front. Microbiol. 2017, 8. [CrossRef] [PubMed]

20. Nguyen, L. Antibiotic resistance mechanisms in M. tuberculosis: An update. Arch. Toxicol. 2016, 90, 1585-1604. [CrossRef] [PubMed]

21. Brauner, A.; Fridman, O.; Gefen, O.; Balaban, N.Q. Distinguishing between resistance, tolerance and persistence to antibiotic treatment. Nat. Rev. Microbiol. 2016, 14, 320-330. [CrossRef] [PubMed]

22. Cohen, N.R.; Lobritz, M.A.; Collins, J.J. Microbial persistence and the road to drug resistance. Cell Host Microbe. 2013, 13, 632-642. [CrossRef]

23. Hameed, H.M.A.; Islam, M.M.; Chhotaray, C.; Wang, C.; Liu, Y.; Tan, Y.; Li, X.; Tan, S.; Delorme, V.; Yew, W.W.; et al. Molecular Targets Related Drug Resistance Mechanisms in MDR- XDR- and TDR-Mycobacterium tuberculosis Strains. Front. Cell Infect. Microbiol. 2018, 8. [CrossRef]

24. Lohrasbi, V.; Talebi, M.; Bialvaei, A.Z.; Fattorini, L.; Drancourt, M.; Heidary, M.; Darban-Sarokhalil, D. Trends in the discovery of new drugs for Mycobacterium tuberculosis therapy with a glance at resistance. Tuberculosis 2018, 109, 17-27. [CrossRef]

25. Islam, M.M.; Hameed, H.M.A.; Mugweru, J.; Chhotaray, C.; Wang, C.; Tan, Y.; Liu, J.; Li, X.; Tan, S.; Ojima, I.; et al. Drug resistance mechanisms and novel drug targets for tuberculosis therapy. J. Genet. Genom. 2017, 44, 21-37. [CrossRef]

26. World Health Organization Regional Office for Europe. Guiding Principles to Reduce Tuberculosis Transmission in the WHO European Region; World Health Organization Regional Office for Europe: Copenhagen, Denmark, 2018. 
27. D'Ambrosio, L.; Bothamley, G.; Caminero Luna, J.A.; Duarte, R.; Guglielmetti, L.; Muñoz Torrico, M.; Payen, M.C.; Saavedra Herrera, N.; Salazar Lezama, M.A.; Skrahina, A.; et al. Team approach to manage difficult-to-treat TB cases: Experiences in Europe and beyond. Pulmonology. 2018, 24, 132-141. [CrossRef] [PubMed]

28. World Association for Infectious Diseases and Immunological Disorders. Available online: http://www. waidid.org/site/workinggroups (accessed on 24 February 2020).

29. Barry, C.E.; Boshoff, H.I.; Dartois, V.; Dick, T.; Ehrt, S.; Flynn, J.; Schnappinger, D.; Wilkinson, R.J.; Young, D. The spectrum of latent tuberculosis: Rethinking the biology and intervention strategies. Nat. Rev. Microbiol. 2009, 7, 845-855. [CrossRef] [PubMed]

30. Lenaerts, A.; Barry, C.E.; Dartois, V. Heterogeneity in tuberculosis pathology, microenvironments and therapeutic responses. Immunol. Rev. 2015, 264, 288-307. [CrossRef] [PubMed]

31. Iacobino, A.; Piccaro, G.; Giannoni, F.; Mustazzolu, A.; Fattorini, L. Fighting tuberculosis by drugs targeting nonreplicating Mycobacterium tuberculosis bacilli. Int. J. Mycobacteriol. 2017, 6, 213-221. [CrossRef] [PubMed]

32. Sarathy, J.P.; Zuccotto, F.; Hsinpin, H.; Sandberg, L.; Via, L.E.; Marriner, G.A.; Masquelin, T.; Wyatt, P.; Ray, P.; Dartois, V. Prediction of Drug Penetration in Tuberculosis Lesions. ACS Infect. Dis. 2016, 2, 552-563. [CrossRef] [PubMed]

33. Lanoix, J.P.; Lenaerts, A.J.; Nuermberger, E.L. Heterogeneous disease progression and treatment response in a C3HeB/FeJ mouse model of tuberculosis. Dis. Model. Mech. 2015, 8, 603-610. [CrossRef]

34. Iacobino, A.; Piccaro, G.; Giannoni, F.; Mustazzolu, A.; Fattorini, L. Activity of drugs against dormant Mycobacterium tuberculosis. Int. J. Mycobacteriol. 2016, 5 (Suppl. 1), S94-S95. [CrossRef]

35. Sarathy, J.P.; Liang, H.H.; Weiner, D.; Gonzales, J.; Via, L.E.; Dartois, V. An In Vitro Caseum Binding Assay that Predicts Drug Penetration in Tuberculosis Lesions. J. Vis. Exp. 2017, 123. [CrossRef]

36. Sarathy, J.P.; Via, L.E.; Weiner, D.; Blanc, L.; Boshoff, H.; Eugenin, E.A.; Barry, C.E.; Dartois, V.A. Extreme Drug Tolerance of Mycobacterium tuberculosis in Caseum. Antimicrob. Agents Chemother. 2018, 62. [CrossRef]

37. Prideaux, B.; Via, L.E.; Zimmerman, M.D.; Eum, S.; Sarathy, J.; O’Brien, P.; Chen, C.; Kaya, F.; Weiner, D.M.; Chen, P.Y.; et al. The association between sterilizing activity and drug distribution into tuberculosis lesions. Nat. Med. 2015, 21, 1223-1227. [CrossRef]

38. Sebastian, J.; Swaminath, S.; Nair, R.R.; Jakkala, K.; Pradhan, A.; Ajitkumar, P. De Novo Emergence of Genetically Resistant Mutants of Mycobacterium tuberculosis from the Persistence Phase Cells Formed against Antituberculosis Drugs In Vitro. Antimicrob. Agents Chemother. 2017, 61. [CrossRef] [PubMed]

39. Nair, R.R.; Sharan, D.; Sebastian, J.; Swaminath, S.; Ajitkumar, P. Heterogeneity of ROS levels in antibiotic-exposed mycobacterial subpopulations confers differential susceptibility. Microbiology. 2019, 165, 668-682. [CrossRef] [PubMed]

40. Piccaro, G.; Pietraforte, D.; Giannoni, F.; Mustazzolu, A.; Fattorini, L. Rifampin induces hydroxyl radical formation in Mycobacterium tuberculosis. Antimicrob. Agents Chemother. 2014, 58, 7527-7533. [CrossRef] [PubMed]

41. Kempker, R.R.; Rabin, A.S.; Nikolaishvili, K.; Kalandadze, I.; Gogishvili, S.; Blumberg, H.M.; Vashakidze, S. Additional drug resistance in Mycobacterium tuberculosis isolates from resected cavities among patients with multidrug-resistant or extensively drug-resistant pulmonary tuberculosis. Clin. Infect. Dis. 2012, 54, e51-e54. [CrossRef] [PubMed]

42. Kaplan, G.; Post, F.A.; Moreira, A.L.; Wainwright, H.; Kreiswirth, B.N.; Tanverdi, M.; Mathema, B.; Ramaswamy, S.V.; Walther, G.; Steyn, L.M.; et al. Mycobacterium tuberculosis growth at the cavity surface: A microenvironment with failed immunity. Infect. Immun. 2003, 71, 7099-7108. [CrossRef]

43. Dheda, K.; Lenders, L.; Magombedze, G.; Srivastava, S.; Raj, P.; Arning, E.; Ashcraft, P.; Bottiglieri, T.; Wainwright, H.; Pennel, T.; et al. Drug-Penetration Gradients Associated with Acquired Drug Resistance in Patients with Tuberculosis. Am. J. Respir. Crit. Care Med. 2018, 198, 1208-1219. [CrossRef]

44. Dulberger, C.L.; Rubin, E.J.; Boutte, C.C. The mycobacterial cell envelope-A moving target. Nat. Rev. Microbiol. 2020, 18, 47-59. [CrossRef]

45. Sarathy, J.P.; Dartois, V.; Lee, E.J. The role of transport mechanisms in Mycobacterium tuberculosis drug resistance and tolerance. Pharmaceuticals 2012, 5, 1210-1235. [CrossRef]

46. Machado, D.; Girardini, M.; Viveiros, M.; Pieroni, M. Challenging the Drug-Likeness Dogma for New Drug Discovery in Tuberculosis. Front. Microbiol. 2018, 9. [CrossRef] 
47. Nguyen, L.; Chinnapapagari, S.; Thompson, C.J. FbpA-Dependent biosynthesis of trehalose dimycolate is required for the intrinsic multidrug resistance, cell wall structure, and colonial morphology of Mycobacterium smegmatis. J. Bacteriol. 2005, 187, 6603-6611. [CrossRef]

48. Liu, J.; Nikaido, H. A mutant of Mycobacterium smegmatis defective in the biosynthesis of mycolic acids accumulates meromycolates. Proc. Natl. Acad. Sci. USA. 1999, 96, 4011-4016. [CrossRef] [PubMed]

49. Singh, A.; Gupta, R.; Vishwakarma, R.A.; Narayanan, P.R.; Paramasivan, C.N.; Ramanathan, V.D.; Tyagi, A.K. Requirement of the mymA operon for appropriate cell wall ultrastructure and persistence of Mycobacterium tuberculosis in the spleens of guinea pigs. J. Bacteriol. 2005, 187, 4173-4186. [CrossRef] [PubMed]

50. Gygli, S.M.; Borrell, S.; Trauner, A.; Gagneux, S. Antimicrobial resistance in Mycobacterium tuberculosis: Mechanistic and evolutionary perspectives. FEMS Microbiol. Rev. 2017, 41, 354-373. [CrossRef] [PubMed]

51. Siroy, A.; Mailaender, C.; Harder, D.; Koerber, S.; Wolschendorf, F.; Danilchanka, O.; Wang, Y.; Heinz, C.; Niederweis, M. Rv1698 of Mycobacterium tuberculosis represents a new class of channel-forming outer membrane proteins. J. Biol. Chem. 2008, 283, 17827-17837. [CrossRef] [PubMed]

52. Chambers, H.F.; Moreau, D.; Yajko, D.; Miick, C.; Wagner, C.; Hackbarth, C.; Kocagöz, S.; Rosenberg, E.; Hadley, W.K.; Nikaido, H. Can penicillins and other beta-lactam antibiotics be used to treat tuberculosis? Antimicrob. Agents Chemother. 1995, 39, 2620-2624. [CrossRef] [PubMed]

53. Quinting, B.; Reyrat, J.M.; Monnaie, D.; Amicosante, G.; Pelicic, V.; Gicquel, B.; Frère, J.M.; Galleni, M. Contribution of beta-lactamase production to the resistance of mycobacteria to beta-lactam antibiotics. FEBS Lett. 1997, 406, 275-278. [CrossRef]

54. Van Rijn, S.P.; Zuur, M.A.; Anthony, R.; Wilffert, B.; van Altena, R.; Akkerman, O.W.; de Lange, W.C.M.; van der Werf, T.S.; Kosterink, J.G.W.; Alffenaar, J.C. Evaluation of Carbapenems for Treatment of Multi- and Extensively Drug-Resistant Mycobacterium tuberculosis. Antimicrob. Agents Chemother. 2019, 63. [CrossRef]

55. Janardhan, S.; Ram Vivek, M.; Narahari Sastry, G. Modeling the permeability of drug-like molecules through the cell wall of Mycobacterium tuberculosis: An analogue based approach. Mol. Biosyst. 2016, 12, 3377-3384. [CrossRef]

56. De Rossi, E.; Aínsa, J.A.; Riccardi, G. Role of mycobacterial efflux transporters in drug resistance: An unresolved question. FEMS Microbiol. Rev. 2006, 30, 36-52. [CrossRef]

57. Rodrigues, L.; Parish, T.; Balganesh, M.; Ainsa, J.A. Antituberculosis drugs: Reducing efflux=increasing activity. Drug Discov. Today. 2017, 22, 592-599. [CrossRef]

58. Srivastava, S.; Musuka, S.; Sherman, C.; Meek, C.; Leff, R.; Gumbo, T. Efflux-pump-derived multiple drug resistance to ethambutol monotherapy in Mycobacterium tuberculosis and the pharmacokinetics and pharmacodynamics of ethambutol. J. Infect. Dis. 2010, 201, 1225-1231. [CrossRef] [PubMed]

59. Machado, D.; Couto, I.; Perdigão, J.; Rodrigues, L.; Portugal, I.; Baptista, P.; Veigas, B.; Amaral, L.; Viveiros, M. Contribution of efflux to the emergence of isoniazid and multidrug resistance in Mycobacterium tuberculosis. PLOS ONE 2012, 7, e34538. [CrossRef] [PubMed]

60. Rodrigues, L.; Villellas, C.; Bailo, R.; Viveiros, M.; Aínsa, J.A. Role of the Mmr efflux pump in drug resistance in Mycobacterium tuberculosis. Antimicrob. Agents Chemother. 2013, 57, 751-757. [CrossRef] [PubMed]

61. Pasca, M.R.; Guglierame, P.; De Rossi, E.; Zara, F.; Riccardi, G. mmpL7 gene of Mycobacterium tuberculosis is responsible for isoniazid efflux in Mycobacterium smegmatis. Antimicrob. Agents Chemother. 2005, 49, 4775-4777. [CrossRef]

62. Hartkoorn, R.C.; Uplekar, S.; Cole, S.T. Cross-resistance between clofazimine and bedaquiline through upregulation of MmpL5 in Mycobacterium tuberculosis. Antimicrob. Agents Chemother. 2014, 58, 2979-2981. [CrossRef]

63. Ismail, N.; Peters, R.P.H.; Ismail, N.A.; Omar, S.V. Clofazimine Exposure In Vitro Selects Efflux Pump Mutants and Bedaquiline Resistance. Antimicrob. Agents Chemother. 2019, 63. [CrossRef]

64. Pule, C.M.; Sampson, S.L.; Warren, R.M.; Black, P.A.; van Helden, P.D.; Victor, T.C.; Louw, G.E. Efflux pump inhibitors: Targeting mycobacterial efflux systems to enhance TB therapy. J. Antimicrob. Chemother. 2016, 71, 17-26. [CrossRef]

65. Chen, C.; Gardete, S.; Jansen, R.S.; Shetty, A.; Dick, T.; Rhee, K.Y.; Dartois, V. Verapamil Targets Membrane Energetics in Mycobacterium tuberculosis. Antimicrob. Agents Chemother. 2018, 62. [CrossRef]

66. Xu, J.; Tasneen, R.; Peloquin, C.A.; Almeida, D.V.; Li, S.Y.; Barnes-Boyle, K.; Lu, Y.; Nuermberger, E. Verapamil Increases the Bioavailability and Efficacy of Bedaquiline but Not Clofazimine in a Murine Model of Tuberculosis. Antimicrob. Agents Chemother. 2017, 62. [CrossRef] 
67. Abbate, E.; Vescovo, M.; Natiello, M.; Cufré, M.; García, A.; Gonzalez Montaner, P.; Ambroggi, M.; Ritacco, V.; van Soolingen, D. Successful alternative treatment of extensively drug-resistant tuberculosis in Argentina with a combination of linezolid, moxifloxacin and thioridazine. J. Antimicrob. Chemother. 2012, 67, $473-477$. [CrossRef]

68. Georghiou, S.B.; Magana, M.; Garfein, R.S.; Catanzaro, D.G.; Catanzaro, A.; Rodwell, T.C. Evaluation of genetic mutations associated with Mycobacterium tuberculosis resistance to amikacin, kanamycin and capreomycin: A systematic review. PLoS ONE 2012, 7, e33275. [CrossRef] [PubMed]

69. Buriánková, K.; Doucet-Populaire, F.; Dorson, O.; Gondran, A.; Ghnassia, J.C.; Weiser, J.; Pernodet, J.L. Molecular basis of intrinsic macrolide resistance in the Mycobacterium tuberculosis complex. Antimicrob. Agents Chemother. 2004, 48, 143-150. [CrossRef] [PubMed]

70. Madsen, C.T.; Jakobsen, L.; Buriánková, K.; Doucet-Populaire, F.; Pernodet, J.L.; Douthwaite, S. Methyltransferase Erm (37) slips on rRNA to confer atypical resistance in Mycobacterium tuberculosis. J. Biol. Chem. 2005, 280, 38942-38947. [CrossRef] [PubMed]

71. Nash, K.A.; Brown-Elliott, B.A.; Wallace, R.J., Jr. A novel gene, erm(41), confers inducible macrolide resistance to clinical isolates of Mycobacterium abscessus but is absent from Mycobacterium chelonae. Antimicrob. Agents Chemother. 2009, 53, 1367-1376. [CrossRef] [PubMed]

72. Khrapunov, S.; Brenowitz, M. Stability, denaturation and refolding of Mycobacterium tuberculosis MfpA, a DNA mimicking protein that confers antibiotic resistance. Biophys. Chem. 2011, 159, 33-40. [CrossRef]

73. Alderwick, L.J.; Harrison, J.; Lloyd, G.S.; Birch, H.L. The Mycobacterial Cell Wall-Peptidoglycan and Arabinogalactan. Cold Spring Harb. Perspect. Med. 2015, 5, a021113. [CrossRef]

74. Gold, B.; Nathan, C. Targeting Phenotypically Tolerant Mycobacterium tuberculosis. Microbiol. Spectr. $2017,5$. [CrossRef]

75. Lipworth, S.; Hammond, R.J.; Baron, V.O.; Hu, Y.; Coates, A.; Gillespie, S.H. Defining dormancy in mycobacterial disease. Tuberculosis 2016, 99, 131-142. [CrossRef]

76. Hammond, R.J.H.; Baron, V.O.; Lipworth, S.; Gillespie, S.H. Enhanced Methodologies for Detecting Phenotypic Resistance in Mycobacteria. Methods Mol. Biol. 2018, 1736, 85-94. [CrossRef]

77. Batyrshina, Y.R.; Schwartz, Y.S. Modeling of Mycobacterium tuberculosis dormancy in bacterial cultures. Tuberculosis 2019, 117, 7-17. [CrossRef]

78. Wayne, L.G.; Hayes, L.G. An in vitro model for sequential study of shiftdown of Mycobacterium tuberculosis through two stages of nonreplicating persistence. Infect. Immun. 1996, 64, 2062-2069. [CrossRef] [PubMed]

79. Sohaskey, C.D.; Voskuil, M.I. In vitro models that utilize hypoxia to induce non-replicating persistence in Mycobacteria. Methods Mol. Biol. 2015, 1285, 201-213. [CrossRef] [PubMed]

80. Betts, J.C.; Lukey, P.T.; Robb, L.C.; McAdam, R.A.; Duncan, K. Evaluation of a nutrient starvation model of Mycobacterium tuberculosis persistence by gene and protein expression profiling. Mol. Microbiol. 2002, 43, 717-731. [CrossRef] [PubMed]

81. Voskuil, M.I.; Schnappinger, D.; Visconti, K.C.; Harrell, M.I.; Dolganov, G.M.; Sherman, D.R.; Schoolnik, G.K. Inhibition of respiration by nitric oxide induces a Mycobacterium tuberculosis dormancy program. J. Exp. Med. 2003, 198, 705-713. [CrossRef]

82. de Carvalho, L.P.; Lin, G.; Jiang, X.; Nathan, C. Nitazoxanide kills replicating and nonreplicating Mycobacterium tuberculosis and evades resistance. J. Med. Chem. 2009, 52, 5789-5792. [CrossRef]

83. Hu, Y.; Mangan, J.A.; Dhillon, J.; Sole, K.M.; Mitchison, D.A.; Butcher, P.D.; Coates, A.R. Detection of mRNA transcripts and active transcription in persistent Mycobacterium tuberculosis induced by exposure to rifampin or pyrazinamide. J. Bacteriol. 2000, 182, 6358-6365. [CrossRef]

84. Sala, C.; Dhar, N.; Hartkoorn, R.C.; Zhang, M.; Ha, Y.H.; Schneider, P.; Cole, S.T. Simple model for testing drugs against nonreplicating Mycobacterium tuberculosis. Antimicrob. Agents Chemother. 2010, 54, 4150-4158. [CrossRef]

85. Jakkala, K.; Ajitkumar, P. Hypoxic Non-replicating Persistent Mycobacterium tuberculosis Develops Thickened Outer Layer That Helps in Restricting Rifampicin Entry. Front. Microbiol. 2019, 10. [CrossRef]

86. Filippini, P.; Iona, E.; Piccaro, G.; Peyron, P.; Neyrolles, O.; Fattorini, L. Activity of drug combinations against dormant Mycobacterium tuberculosis. Antimicrob. Agents Chemother. 2010, 54, 2712-2715. [CrossRef]

87. Piccaro, G.; Giannoni, F.; Filippini, P.; Mustazzolu, A.; Fattorini, L. Activities of drug combinations against Mycobacterium tuberculosis grown in aerobic and hypoxic acidic conditions. Antimicrob. Agents Chemother. 2013, 57, 1428-1433. [CrossRef] 
88. Iacobino, A.; Piccaro, G.; Giannoni, F.; Mustazzolu, A.; Fattorini, L. Mycobacterium tuberculosis Is Selectively Killed by Rifampin and Rifapentine in Hypoxia at Neutral pH. Antimicrob. Agents Chemother. 2017, 61. [CrossRef] [PubMed]

89. Iacobino, A.; Giannoni, F.; Pardini, M.; Piccaro, G.; Fattorini, L. The Combination Rifampin-Nitazoxanide, but Not Rifampin-Isoniazid-Pyrazinamide-Ethambutol, Kills Dormant Mycobacterium tuberculosis in Hypoxia at Neutral pH. Antimicrob. Agents Chemother. 2019, 63. [CrossRef] [PubMed]

90. Orman, M.A.; Brynildsen, M.P. Dormancy is not necessary or sufficient for bacterial persistence. Antimicrob. Agents Chemother. 2013, 57, 3230-3239. [CrossRef] [PubMed]

91. Keren, I.; Minami, S.; Rubin, E.; Lewis, K. Characterization and transcriptome analysis of Mycobacterium tuberculosis persisters. MBio 2011, 2, e00100-11. [CrossRef]

92. Lenaerts, A.J.; Hoff, D.; Aly, S.; Ehlers, S.; Andries, K.; Cantarero, L.; Orme, I.M.; Basaraba, R.J. Location of persisting mycobacteria in a Guinea pig model of tuberculosis revealed by r207910. Antimicrob. Agents Chemother. 2007, 51, 3338-3345. [CrossRef]

93. Liu, Y.; Pertinez, H.; Ortega-Muro, F.; Alameda-Martin, L.; Harrison, T.; Davies, G.; Coates, A.; Hu, Y. Optimal doses of rifampicin in the standard drug regimen to shorten tuberculosis treatment duration and reduce relapse by eradicating persistent bacteria. J. Antimicrob. Chemother. 2018, 73, 724-731. [CrossRef]

94. Hu, Y.; Pertinez, H.; Liu, Y.; Davies, G.; Coates, A. Bedaquiline kills persistent Mycobacterium tuberculosis with no disease relapse: An in vivo model of a potential cure. J. Antimicrob. Chemother. 2019, 74, 1627-1633. [CrossRef]

95. Xu, J.; Li, S.Y.; Almeida, D.V.; Tasneen, R.; Barnes-Boyle, K.; Converse, P.J.; Upton, A.M.; Mdluli, K.; Fotouhi, N.; Nuermberger, E.L. Contribution of Pretomanid to Novel Regimens Containing Bedaquiline with either Linezolid or Moxifloxacin and Pyrazinamide in Murine Models of Tuberculosis. Antimicrob. Agents Chemother. 2019, 63. [CrossRef]

96. Van den Bergh, B.; Fauvart, M.; Michiels, J. Formation, physiology, ecology, evolution and clinical importance of bacterial persisters. FEMS Microbiol. Rev. 2017, 41, 219-251. [CrossRef]

97. Pang, Y.; Zong, Z.; Huo, F.; Jing, W.; Ma, Y.; Dong, L.; Li, Y.; Zhao, L.; Fu, Y.; Huang, H. In Vitro Drug Susceptibility of Bedaquiline, Delamanid, Linezolid, Clofazimine, Moxifloxacin, and Gatifloxacin against Extensively Drug-Resistant Tuberculosis in Beijing, China. Antimicrob. Agents Chemother. 2017, 61. [CrossRef]

98. Miotto, P.; Tessema, B.; Tagliani, E.; Chindelevitch, L.; Starks, A.M.; Emerson, C.; Hanna, D.; Kim, P.S.; Liwski, R.; Zignol, M.; et al. A standardised method for interpreting the association between mutations and phenotypic drug resistance in Mycobacterium tuberculosis. Eur. Respir. J. 2017, 50. [CrossRef]

99. Mahmood, N.; Abbas, S.N.; Faraz, N.; Shahid, S. Mutational analysis of $g y r B$ at amino acids: G481A \& D505A in multidrug resistant (MDR) tuberculosis patients. J. Infect. Public Health. 2019, 12, 496-501. [CrossRef] [PubMed]

100. Ismail, N.; Omar, S.V.; Ismail, N.A.; Peters, R.P.H. Collated data of mutation frequencies and associated genetic variants of bedaquiline, clofazimine and linezolid resistance in Mycobacterium tuberculosis. Data Brief. 2018, 20, 1975-1983. [CrossRef] [PubMed]

101. Ismail, N.; Ismail, N.A.; Omar, S.V.; Peters, R.P.H. In Vitro Study of Stepwise Acquisition of rv0678 and atpE Mutations Conferring Bedaquiline Resistance. Antimicrob. Agents Chemother. 2019, 63. [CrossRef] [PubMed]

102. Pi, R.; Liu, Q.; Jiang, Q.; Gao, Q. Characterization of linezolid-resistance-associated mutations in Mycobacterium tuberculosis through WGS. J. Antimicrob. Chemother. 2019, 74, 1795-1798. [CrossRef] [PubMed]

103. Zhang, S.; Chen, J.; Cui, P.; Shi, W.; Zhang, W.; Zhang, Y. Identification of novel mutations associated with clofazimine resistance in Mycobacterium tuberculosis. J. Antimicrob. Chemother. 2015, 70, 2507-2510. [CrossRef]

104. Almeida, D.; Ioerger, T.; Tyagi, S.; Li, S.Y.; Mdluli, K.; Andries, K.; Grosset, J.; Sacchettini, J.; Nuermberger, E. Mutations in $p e p Q$ Confer Low-Level Resistance to Bedaquiline and Clofazimine in Mycobacterium tuberculosis. Antimicrob. Agents Chemother. 2016, 60, 4590-4599. [CrossRef]

105. Evangelopoulos, D.; Prosser, G.A.; Rodgers, A.; Dagg, B.M.; Khatri, B.; Ho, M.M.; Gutierrez, M.G.; Cortes, T.; de Carvalho, L.P.S. Comparative fitness analysis of D-cycloserine resistant mutants reveals both fitness-neutral and high-fitness cost genotypes. Nat. Commun. 2019, 10, 4177. [CrossRef]

106. Sun, Q.; Xiao, T.Y.; Liu, H.C.; Zhao, X.Q.; Liu, Z.G.; Li, Y.N.; Zeng, H.; Zhao, L.L.; Wan, K.L. Mutations within embCAB Are Associated with Variable Level of Ethambutol Resistance in Mycobacterium tuberculosis Isolates from China. Antimicrob. Agents Chemother. 2017, 62. [CrossRef] 
107. Chen, X.; He, G.; Wang, S.; Lin, S.; Chen, J.; Zhang, W. Evaluation of Whole-Genome Sequence Method to Diagnose Resistance of 13 Anti-tuberculosis Drugs and Characterize Resistance Genes in Clinical Multi-Drug Resistance Mycobacterium tuberculosis Isolates From China. Front. Microbiol. 2019, 10. [CrossRef]

108. Lingaraju, S.; Rigouts, L.; Gupta, A.; Lee, J.; Umubyeyi, A.N.; Davidow, A.L.; German, S.; Cho, E.; Lee, J.I.; Cho, S.N.; et al. Geographic Differences in the Contribution of $u b i A$ Mutations to High-Level Ethambutol Resistance in Mycobacterium tuberculosis. Antimicrob. Agents Chemother. 2016, 60, 4101-4105. [CrossRef] [PubMed]

109. He, L.; Wang, X.; Cui, P.; Jin, J.; Chen, J.; Zhang, W.; Zhang, Y. ubiA (Rv3806c) encoding DPPR synthase involved in cell wall synthesis is associated with ethambutol resistance in Mycobacterium tuberculosis. Tuberculosis 2015, 95, 149-154. [CrossRef] [PubMed]

110. Fujiwara, M.; Kawasaki, M.; Hariguchi, N.; Liu, Y.; Matsumoto, M. Mechanisms of resistance to delamanid, a drug for Mycobacterium tuberculosis. Tuberculosis 2018, 108, 186-194. [CrossRef] [PubMed]

111. Nusrath Unissa, A.; Hanna, L.E. Molecular mechanisms of action, resistance, detection to the first-line anti tuberculosis drugs: Rifampicin and pyrazinamide in the post whole genome sequencing era. Tuberculosis 2017, 105, 96-107. [CrossRef] [PubMed]

112. Shi, W.; Chen, J.; Zhang, S.; Zhang, W.; Zhang, Y. Identification of Novel Mutations in LprG (rv1411c), rv0521, rv3630, rv0010c, ppsC and cyp128 Associated with Pyrazinoic Acid/Pyrazinamide Resistance in Mycobacterium tuberculosis. Antimicrob. Agents Chemother. 2018, 62. [CrossRef]

113. Zhang, S.; Chen, J.; Shi, W.; Cui, P.; Zhang, J.; Cho, S.; Zhang, W.; Zhang, Y. Mutation in clpC1 encoding an ATP-dependent ATPase involved in protein degradation is associated with pyrazinamide resistance in Mycobacterium tuberculosis. Emerg. Microbes Infect. 2017, 6. [CrossRef]

114. Lun, S.; Miranda, D.; Kubler, A.; Guo, H.; Maiga, M.C.; Winglee, K.; Pelly, S.; Bishai, W.R. Synthetic lethality reveals mechanisms of Mycobacterium tuberculosis resistance to $\beta$-lactams. MBio 2014, 5, e1767-14. [CrossRef]

115. Cohen, K.A.; El-Hay, T.; Wyres, K.L.; Weissbrod, O.; Munsamy, V.; Yanover, C.; Aharonov, R.; Shaham, O.; Conway, T.C.; Goldschmidt, Y.; et al. Paradoxical Hypersusceptibility of Drug-resistant Mycobacterium tuberculosis to $\beta$-lactam Antibiotics. EBioMedicine. 2016, 9, 170-179. [CrossRef]

116. Iannazzo, L.; Soroka, D.; Triboulet, S.; Fonvielle, M.; Compain, F.; Dubée, V.; Mainardi, J.L.; Hugonnet, J.E.; Braud, E.; Arthur, M.; et al. Routes of Synthesis of Carbapenems for Optimizing Both the Inactivation of L,D-Transpeptidase LdtMt1 of Mycobacterium tuberculosis and the Stability toward Hydrolysis by $\beta$-Lactamase BlaC. J. Med. Chem. 2016, 59, 3427-3438. [CrossRef]

117. Ramakrishna, V.; Singh, P.K.; Prakash, S.; Jain, A. Second Line Injectable Drug Resistance and Associated Genetic Mutations in Newly Diagnosed Cases of Multidrug-Resistant Tuberculosis. Microb. Drug Resist. 2020. [CrossRef]

118. Perdigão, J.; Portugal, I. Genetics and roadblocks of drug resistant tuberculosis. Infect. Genet. Evol. 2019, 72, 113-130. [CrossRef] [PubMed]

119. Verma, J.S.; Gupta, Y.; Nair, D.; Manzoor, N.; Rautela, R.S.; Rai, A.; Katoch, V.M. Evaluation of gidB alterations responsible for streptomycin resistance in Mycobacterium tuberculosis. J. Antimicrob. Chemother. 2014, 69, 2935-2941. [CrossRef] [PubMed]

120. Wong, S.Y.; Lee, J.S.; Kwak, H.K.; Via, L.E.; Boshoff, H.I.; Barry, C.E. Mutations in gidB confer low-level streptomycin resistance in Mycobacterium tuberculosis. Antimicrob. Agents Chemother. 2011, 55, 2515-2522. [CrossRef]

121. Hicks, N.D.; Carey, A.F.; Yang, J.; Zhao, Y.; Fortune, S.M. Bacterial Genome-Wide Association Identifies Novel Factors That Contribute to Ethionamide and Prothionamide Susceptibility in Mycobacterium tuberculosis. MBio 2019, 10. [CrossRef]

122. Rueda, J.; Realpe, T.; Mejia, G.I.; Zapata, E.; Rozo, J.C.; Ferro, B.E.; Robledo, J. Genotypic Analysis of Genes Associated with Independent Resistance and Cross-Resistance to Isoniazid and Ethionamide in Mycobacterium tuberculosis Clinical Isolates. Antimicrob. Agents Chemother. 2015, 59, 7805-7810. [CrossRef] [PubMed]

123. Grant, S.S.; Wellington, S.; Kawate, T.; Desjardins, C.A.; Silvis, M.R.; Wivagg, C.; Thompson, M.; Gordon, K.; Kazyanskaya, E.; Nietupski, R.; et al. Baeyer-Villiger Monooxygenases EthA and MymA Are Required for Activation of Replicating and Non-replicating Mycobacterium tuberculosis Inhibitors. Cell Chem. Biol. 2016, 23, 666-677. [CrossRef]

124. Pandey, B.; Grover, S.; Kaur, J.; Grover, A. Analysis of mutations leading to para-aminosalicylic acid resistance in Mycobacterium tuberculosis. Sci. Rep. 2019, 9. [CrossRef] 
125. Wei, W.; Yan, H.; Zhao, J.; Li, H.; Li, Z.; Guo, H.; Wang, X.; Zhou, Y.; Zhang, X.; Zeng, J.; et al. Multi-omics comparisons of p-aminosalicylic acid (PAS) resistance in folC mutated and un-mutated Mycobacterium tuberculosis strains. Emerg. Microbes Infect. 2019, 8, 248-261. [CrossRef]

126. Dookie, N.; Rambaran, S.; Padayatchi, N.; Mahomed, S.; Naidoo, K. Evolution of drug resistance in Mycobacterium tuberculosis: A review on the molecular determinants of resistance and implications for personalized care. J. Antimicrob. Chemother. 2018, 73, 1138-1151. [CrossRef]

127. Meehan, C.J.; Goig, G.A.; Kohl, T.A.; Verboven, L.; Dippenaar, A.; Ezewudo, M.; Farhat, M.R.; Guthrie, J.L.; Laukens, K.; Miotto, P.; et al. Whole genome sequencing of Mycobacterium tuberculosis: Current standards and open issues. Nat. Rev. Microbiol. 2019, 17, 533-545. [CrossRef]

128. World Health Organization. The Use of Next-Generation Sequencing Technologies for the Detection of Mutations Associated with Drug Resistance in Mycobacterium tuberculosis Complex: Technical Guide; World Health Organization: Geneva, Switzerland, 2018.

129. Pipeline Report 2019. Diagnostics. Treatment Action Group (TAG). Available online: https://www. treatmentactiongroup.org/wp-content/uploads/2019/12/pipeline_tb_diagnotics_2019_db_final.pdf (accessed on 24 February 2020).

130. World Health Organization. Rapid Communication: Molecular Assays as Initial Test for the Diagnosis of Tuberculosis and Rifampicin Resistance. Available online: https:/apps.who.int/iris/bitstream/handle/10665/ 330395/9789240000339-eng.pdf (accessed on 24 February 2020).

131. Beutler, M.; Plesnik, S.; Mihalic, M.; Olbrich, L.; Heinrich, N.; Schumacher, S.; Lindner, M.; Koch, I.; Grasse, W.; Metzger-Boddie, C.; et al. A Pre-Clinical Validation Plan to Evaluate Analytical Sensitivities of Molecular Diagnostics Such as BD MAX MDR-TB, Xpert MTB/Rif Ultra and FluoroType MTB. PLoS ONE 2020, 15, e0227215. [CrossRef] [PubMed]

132. Ruiz, P.; Causse, M.; Vaquero, M.; Gutierrez, J.B.; Casal, M. Evaluation of a New Automated Abbott RealTime MTB RIF/INH Assay for Qualitative Detection of Rifampicin/Isoniazid Resistance in Pulmonary and Extra-Pulmonary Clinical Samples of Mycobacterium tuberculosis. Infect. Drug Resist. 2017, 10, 463-467. [CrossRef] [PubMed]

133. de Vos, M.; Derendinger, B.; Dolby, T.; Simpson, J.; van Helden, P.D.; Rice, J.E.; Wangh, L.J.; Theron, G.; Warren, R.M. Diagnostic Accuracy and Utility of FluoroType MTBDR, a New Molecular Assay for Multidrug-Resistant Tuberculosis. J. Clin. Microbiol. 2018, 56. [CrossRef] [PubMed]

134. Advani, J.; Verma, R.; Chatterjee, O.; Pachouri, P.K.; Upadhyay, P.; Singh, R.; Yadav, J.; Naaz, F.; Ravikumar, R.; Buggi, S.; et al. Whole Genome Sequencing of Mycobacterium tuberculosis Clinical Isolates From India Reveals Genetic Heterogeneity and Region-Specific Variations That Might Affect Drug Susceptibility. Front. Microbiol. 2019, 10. [CrossRef] [PubMed]

135. Allix-Béguec, C.; Arandjelovic, I.; Bi, L.; Beckert, P.; Bonnet, M.; Bradley, P.; Cabibbe, A.M.; Cancino-Muñoz, I.; Caulfield, M.J.; Chaiprasert, A.; et al. Prediction of Susceptibility to First-Line Tuberculosis Drugs by DNA Sequencing. N. Engl. J. Med. 2018, 379, 1403-1415. [CrossRef] [PubMed]

(C) 2020 by the authors. Licensee MDPI, Basel, Switzerland. This article is an open access article distributed under the terms and conditions of the Creative Commons Attribution (CC BY) license (http://creativecommons.org/licenses/by/4.0/). 